\title{
ANALISIS KINERJA SATUAN LALU LINTAS DALAM MENINGKATKAN KETERTIBAN LALU LINTAS DI KOTA BANDAR LAMPUNG
}

\author{
Erwin Putubasai \\ Fakultas Ilmu Sosial dan Ilmu Politik Universitas Sang Bumi Ruwa Jurai \\ erwinputubasai@gmail.com
}

\begin{abstract}
ABSTRAK
Tujuan penelitian ini adalah untuk mengetahui kinerja Satuan Lalu Lintas Kepolisian Resort Kota (Polresta) Bandar Lampung dalam upayanya untukmeningkatkan ketertiban lalu lintas di Kota Bandar Lampung. Subjek dalam penelitian adalah Satuan Lalu Lintas Polresta Bandar Lampung. Objek penelitian adalah anggota Satuan Lalu Lintas Polresta Bandar Lampung, dengan sampel sebanyak enam (6) orang. Teknik pengumpulan data yang penulis lakukan adalahInterview/wawancara, pengamatan langsung di lapangan, dokumentasi dan studi pustaka. Analisa data yang digunakan adalah analisis kualitatif.Berdasakan hasil penelitian dapat diketahui Satuan Lalu Lintas Polresta Bandar Lampung, sudah melaksanakan tugas pokok dan fungsinya yaitu bertugas untuk menyelenggarakan dan membina fungsi lalulintas kepolisian, meliputi penjagaan, pengaturan, pengawalan dan patroli, pendidikan masyarakat dan rekayasa lalulintas, registrasi dan identifikasi, penyidikan kecelakaan lalu lintas dan penegakan hukum bidang lalulintas, guna memelihara keamanan, keselamatan, ketertiban dan kelancaran lalulintas. Pelaksanaan tugas pokok dan fungsi Satuan Lalu Lintas Polresta Bandar Lampung tersebut membuktikan bahwa kinerja Satuan Lalu Lintas Polresta Bandar Lampung sudah terlaksana dengan baik.
\end{abstract}

Kata kunci : kinerja, ketertiban, lalu lintas

\section{ABSTRACT}

The aim of this research is to know the performance of Police Resort (Polresta) in Bandar Lampung City in its efforts to improve traffic order in Bandar Lampung City. The subject in the study was the Bandar Lampung Police Traffic Unit. The object of research is a member of the Bandar Lampung Police Traffic Unit, with a sample of six(6) people.Data collection techniques that the authors do are interview, direct observation in the field (observation), documentation and literature study. Analysis of the data used is qualitative analysis.Based on the results of the research, it can be seen that the Bandar Lampung Police Traffic Unit has carried out its main duties and functions, namely to carry out and foster police traffic functions, including guarding, regulating, escorting and patrolling, community education and traffic engineering, registration and identification, investigation traffic accidents and law enforcement in the field of traffic, in order to maintain security, safety, order and smooth traffic. The implementation of the main tasks and functions of the Bandar Lampung Police Traffic.

Keywords : performance, order, traffic 
PENDAHULUAN

Tuntutan tugas Kepolisian Republik Indonesia dari berbagai elemen masyarakat yang semakin meningkat, membuat organisasi ini harus bekerja ekstra keras untuk mengimbangi hal tersebut. Kritik-kritik dari masyarakat akan kinerja Kepolisian Republik Indonesia yang seolah-olah tidak pernah puas akan kerja yang dilakukan oleh organisasi ini, kinerja menurut Moeheriono (2012:95) yaitu performance yang merupakan gambaran mengenai tingkat pencapaian pelaksanaan suatu program kegiatan atau kebijakan dalam mewujudkan sasaran, tujuan, visi dan misi organisasi yang dituangkan melalui perencanaan strategis suatu organisasi. Sehingga Kepolisian Republik Indonesia melakukan berbagai upaya untuk membangun citra yang baik sebagai perwujudan Good Governance.

\section{Berdasarkan Undang-undang} Nomor 17 Tahun 2007 tentang Rencana Pembangunan Jangka Panjang Nasional (RPJPN) tahun 2005-2025, Kepolisian Republik Indonesia mencetuskan Grand StrategyKepolisian Republik Indonesia tahun 2005-2025, yang mencakup 3 (tiga) tahapan waktu, yaitu : a. Tahap I yang telah dilaksanakan pada tahun 2005-2009 laludifokuskan pada membangun kepercayaan (trust building);

b. Tahap II yang dilaksanakan pada tahun 2010-2014 adalah untuk membangun kemitraan (partnership building);

c. Tahap III tahun 2015-2025 menuju organisasi unggulan (strive for excellence).

Grand Strategy Kepolisian Republik Indonesia ini merupakan landasan bagi Kepolisian Republik Indonesia untuk melakukan pembenahan dalam tubuh organisasi ini guna meningkatkan kinerja Kepolisian Republik Indonesia dalam upayanya untuk memantapkan organisasi Kepolisian Republik Indonesia yang kuat dan mampu melaksanakan tugasnya sebagai pelindung, pengayom dan pelayan masyarakat serta sekaligus sebagai penegak hukum yang dipercaya oleh rakyat.

Sebagai tindak lanjut dari Grand Strategy Kepolisian Republik Indonesia ini kemudian dicanangkan Reformasi Birokrasi Kepolisian Republik Indonesia (RBP) yang dibuat agar sejalan dengan agenda reformasi birokrasi pemerintahan, dimana setidaknya terdapat 8 (delapan) bidang/area/program yang menjadi agenda reformasi birokrasi, yaitu : 
a. Area/bidang organisasi, yaitu dengan mewujudkan organisasi yang tepat fungsi/tepat ukuran;

b. Area/bidang tata laksana, yaitu sistem, proses dan prosedur yg jelas, efektif, efisien, terukur, sesuai dengan prisnipprinsip good governance;

c. Area/bidang peraturan/undangundang, yaitu adanya regulasi yang tertib/tidak tumpang tindih;

d. Area/bidang sumber daya manusia, yaitu terwujudnya sumber daya manusia (SDM) yang berintegritas, netral, kompeten, kompatibel, berkinerja tinggi dan sejahtera;

e. Area/bidang pengawasan, yaitu meningkatnya penyelenggaraan pemerintahan yang bersih dan bebas dari Korupsi, Kolusi, dan Nepotisme;

f. Area/bidang akuntabilitas, yaitu meningkatnya kapasitas dan akuntabilitas kinerja birokrasi;

g. Area/bidang pelayanan publik, yaitu terwujudnya pelayanan prima sesuai kebutuhan dan harapan masyarakat;

h. Area/bidang pola pikir dan budaya kerja, yaitu birokrasi dengan integritas dan kinerja yang tinggi.

\section{Reformasi Birokrasi Kepolisian}

Republik Indonesia (RBP) yang dicetuskan pertama kali pada tahun 2008. Menurut Sedarmayanti (2009:72), mengatakan bahwa reformasi birokrasi merupakan upaya pemerintah untuk meningkatkan kinerja melalui berbagai cara dengan tujuan efektifitas, efisien, dan akuntabilitas Kepolisian mengawalinya dengan peluncuran suatu program yang bertujuan untuk menunjang keberhasilan dan meningkatkan kepercayaan serta kecintaan publik (masyarakat) kepada institusi Kepolisian Republik Indonesia dalam waktu cepat, serta berubahnya pola pikir (mind set) dan budaya kerja (culture set) maupun manajemen Kepolisian Republik Indonesia, maka perlu dilakukan pemilihan program yang langsung dapat dirasakan oleh masyarakat. Program ini disebut dengan istilah Quick Wins atau program keberhasilan segera.

Program ini merupakan wujud dari keseriusan Kepolisian Republik Indonesia untuk melakukan perubahan sebagai upaya peningkatan kualitas kinerja dalam menjalankan tugas pokok Kepolisian Republik Indonesia dengan menerapkan prinsip-prinsip transparansi dan akuntabilitas. Menurut Penny Kusumastuti (2014:2) Akuntabilitas adalah bentuk kewajiban penyedia penyelenggaraan kegiatan publik untuk dapat menjelaskan dan menjawab segala hal menyangkut langkah dari seluruh keputusan dan proses yang dilakukan, 
serta pertanggungjawaban terhadap hasil kinerjanya sebagai bentuk kewajiban kepolisian dalam menyelenggarakan kegiatan publik dan dapat menjelaskan serta menjawab segala hal menyangkut langkah dari seluruh keputusan dan proses yang dilakukan, serta pertanggungjawaban terhadap hasil kinerjanya.

\section{Saat ini Reformasi Birokrasi} Kepolisian Republik Indonesia (RBP) sudah memasuki agenda gelombang kedua (2011 - 2014). Perbedaan yang signifikan antara gelombang I dengan gelombang II yaitu gelombang I bersifat instansional sedangkan untuk gelombang II disamping melanjutkan instansional juga bersifat nasional.Implementasi Reformasi Birokrasi Kepolisian Republik Indonesia (RBP) pada masing-masing bidang tugas satuan fungsi adalah untuk mempercepat tercapainya perubahan sebagai upaya peningkatan kualitas kinerja dalam menjalankan tugas pokok Kepolisian Republik Indonesia.

Menindaklanjuti program Reformasi Birokrasi Kepolisian Republik Indonesia (RBP) Gelombang II tahun 2011-2014 fungsi lalulintas di khususkan pada program peningkatan kualitas pelayanan publik. Pelayanan publik adalah pemberian jasa, baik oleh pemerintah, pihak swasta atas nama pemerintah, ataupun pihak swasta kepada masyarakat, dengan atau tanpa pembayaran guna memenuhi kebutuhan dan atau kepentingan masyarakat (Panji Santosa 2009:57).

Hal ini dikarenakan padafungsi lalulintas terdapat banyak sekali pelayanan yang diberikan kepada masyarakat, diantaranya penerbitan Surat Izin Mengemudi (SIM), pelayanan penanganan kecelakaan lalu lintas, pelayanan pengawalan kegiatan masyarakat, pelayananan penanganan kemacetan lalu lintas dan lain-lain yang terkait dengan keamanan, keselamatan, ketertiban, dan kelancaran lalulintas.

Berdasarkan Keputusan Kapolri Nomor : Kep/366/VI/2010 Pasal 21 ayat 2, bahwa "Satuan lalulintas adalah salah satu fungsi Kepolisian Republik Indonesia di tingkat Polres (wilayah kota atau kabupaten di Indonesia) yang bertugas untuk menyelenggarakan dan membina fungsi lalulintas kepolisian, yang meliputi penjagaan, pengaturan, pengawalan dan patroli, pendidikan masyarakat dan rekayasa lalulintas, registrasi dan identifikasi pengemudi/kendaraan bermotor, penyidikan kecelakaan lalu lintas dan penegakan hukum bidang lalulintas, 
guna memelihara keamanan, keselamatan, ketertiban dan kelancaran lalulintas".

Menghadapi kendala-kendala yang terkait dengan lalulintas di jalan raya, Satuan Lalu Lintas dituntut untuk mampu melakukan inovasi dalam peningkatan kualitas pelayanan untuk mewujudkan keamanan, keselamatan, ketertiban dan kelancaran lalulintas (kamseltibcar lantas).Hubungan timbal balik antara petugas satuan lalulintas sebagai aparat penegak hukum dengan masyarakat pengguna jalan dalam bentuk partisipasi untuk tertib dalam berlalulintas terus ditingkatkan guna mendapatkan simpati dalam menciptakan keamanan, keselamatan, ketertiban dan kelancaran lalulintas.

Guna mendapatkan partisipasi masyarakat tersebut berbagai upaya dilakukan oleh Satuan Lalu Lintas, diantaranya membangun kemitraan dalam bidang lalulintas yang dirancang dengan program yang diberi nama "Road SafetyPartnership Action (RSPA)", yaitu program yang dirancang untuk mendapatkan partisipasi dari masyarakat pengguna jalan dalam menciptakan keamanan, keselamatan, ketertiban dankelancaran lalulintas (Kamseltibcar Lantas) dengan mengedepankan Unit Pendidikan, dan
Rekayasa Lalulintas (Dikyasa Lantas) sebagai pelaksana utama kegiatan tersebut.

Satuan Lalu Lintas Polresta Bandar Lampung adalah organisasi Kepolisian Republik Indonesia tingkat Kepolisian Resort Kota yang bertanggungjawab dalam menciptakan situasi lalulintas yang kondusif di wilayah Kota Bandar Lampung.Sebagaimana kita ketahui bahwa Kota Bandar Lampung adalah merupakan salah satu kota dengan populasi kendaraan bermotor yang semakin hari semakin bertambah banyak jumlahnya.

\section{Berdasarkan catatan Dinas} Pendapatan Daerah (Dispenda) Propinsi Lampung bahwa jumlah kendaraan di Kota Bandar Lampung sampai dengan bulan Agustus untuk kendaraan roda 2 (dua) sebanyak 132.011 unit sedangkan kendaraan roda 4 sebanyak 55.980 unit. Data jumlah kendaraan tersebut berdasarkan dokumentasi Samsat yaitu jumlah kendaraan yang telah dibayar pajaknya oleh pemilik kendaraan.

Semakin bertambahnya jumlah kendaraan, tanpa diimbangi oleh penambahan sarana dan prasarana jalan menyebabkan jalan raya semakin padat oleh arus kendaraan bermotor. Perilaku pengguna jalan yang tidak tertib membuat kondisi lalulintas semakin tidak teratur, sehingga dapat menimbulkan berbagai permasalahan, antara lain kemacetan 
lalulintas bahkan banyak terjadinya kecelakaan lalulintas.

Berdasarkan informasi yang penulis dapatkan dari Satuan Lalu Lintas Kepolisian Resort Kota (Polresta) Bandar Lampung bahwa angka pelanggaran lalu lintas dan angka kecelakaan lalu lintas dari tahun ke tahun di Kota Bandar Lampung masih cukup tinggi. Tingginya angka pelanggaran lalu lintas dan angka kecelakaan lalu lintas berdasarkan informasi dari Satuan Lalu Lintas Kepolisian Resort Kota (Polresta) Bandar Lampung disebabkan antara lain; bertambah banyaknya jumlah kendaraan, baik roda dua maupun roda empat yang tidak diimbangi dengan penambahan dan perbaikan sarana dan prasarana jalan raya, prilaku pengendara yang mau menang sendiri, pengendara tidak mengindahkan peraturan lalu lintas seperti surat-surat kendaraan tidak lengkap (SIM dan STNK) tidak memakai helm bagi kendaraan roda dua, tidak memakai sabuk pengaman bagi kendaraan roda empat dan lain-lain, rambu-rambu lalu lintas banyak yang tidak berfungsi dengan baik serta masih kurangnya kesadaran masyarakat akan pentingnya ketertiban dan keamanan dalam ber lalu lintas.

Kesadaran masyarakat sangat dibutuhkan dalam menciptakan ketertiban berlalulintas, hal ini akan terwujud jika ada kesadaran yang baik dari warga masyarakat untuk mematuhi hukum dan penegakan hukum oleh aparat yang berwenang. Chaerudin Ismail (1998:55), menyatakan harapanharapan mana menuntut peranan warga masyarakat di dalam mendukung tugastugas kepolisian. Pada dasarnya, polisi mengharapkan ketaatan itu, maka pekerjaan polisi akan menjadi mudah dan efektif. Polisi juga mengharapkan keikutsertaan warga masyarakat dalam usaha pencegahan kejahatan dan pemeliharaan ketertiban umum.

Dampak dari masih tingginya angka pelanggaran lalu lintas di wilayah Resort Kepolisian Kota Bandar Lampung mengakibatkan angka kecelakaan lalu lintas masih cukup tinggi sehingga banyak menimbulkan korban, baik korban jiwa, luka berat maupun luka ringan.

Adanya permasalahan tersebut di atas, maka tujuan dari diadakannya penelitian ini tujuannya adalah untuk mengetahui Kinerja Satuan Lalu Lintas Kepolisian Resort Kota (Polresta) Bandar Lampung Dalam Meningkatkan Ketertiban Lalu Lintas di Kota Bandar Lampung. 


\section{METODE PENELITIAN}

Langkah atau tahapan-tahapan yang penulis lakukan dalam penelitian ini adalah; memilih masalah, merumuskan masalah, merumuskan hipotesis, menentukan variabel dan sumber data, menyusun alat pengumpul data, mengumpulkan data, menganalisis data, memberikan kesimpulan, serta menulis laporan.

Penelitian ini difokuskan pada masalah kinerja Satuan Lalu Lintas Polresta Bandar Lampung dalam meningkatkan ketertiban lalu lintas di Kota Bandar Lampung.Subjek penelitian ini adalah personil Satuan Lalu Lintas Polresta Bandar Lampung, sedangkan sumber informasi (sampel) yang penulis tetapkan dalam penelitian ini sebanyak 6 orang personil yang mempunyai jabatan penting di Satuan Lalu Lintas Polresta Bandar Lampung yaitu; Kaurbin Ops, Kaurmin, Kanit Turjawali, Kanit Regident, Kanit Dikyasa dan Kanit Laka.

$$
\text { Sampel tersebut cukup }
$$
meyakinkan dan dapat dipercaya untuk memberikan keterangan yang objektif terkait dengan kinerja dan ketertiban lalu lintas di Polresta Bandar Lampung. Selain itu para sampel tersebut sangat mengatahui permasalahan lalu lintas di wilayah kerja Polresta Bandar Lampung. Teknik pengumpulan data yang penulis gunakan adalah teknik Interview/wawancara, dokumentasi, observasi dan studi pustaka.

Analisa yang penulis gunakan untuk menganalisa data adalah analisa kualitatif, yang diinterpretasikan untuk mengambil suatu kesimpulan.

\section{HASIL DAN PEMBAHASAN}

Satuan lalulintas adalah salah satu fungsi Kepolisian Republik Indonesia di tingkat Polres (wilayah kota atau kabupaten di Indonesia) yang bertugas untuk menyelenggarakan dan membina fungsi lalulintas kepolisian, yang meliputi penjagaan, pengaturan, pengawalan dan patroli, pendidikan masyarakat dan rekayasa lalulintas, registrasi dan identifikasi pengemudi/kendaraan bermotor, penyidikan kecelakaan lalu lintas dan penegakan hukum bidang lalulintas, guna memelihara keamanan, keselamatan, ketertiban dan kelancaran lalulintas".

Kesatuan Lalu Lintas Polresta Bandar Lampung sebagai unsur pembantu pimpinan dan pelaksanaan 
ditingkat Polresta Bandar Lampung, yang bertugas melaksanakan pembinaan dan bimbingan fungsi tehnis Lantas didalam lingkungan Polresta Bandar Lampung, serta menyelenggarakan dan melaksanakan fungsi tersebut bersifat Regional,terpusat serta mendukung pelaksanaan tugas operasional pada tingkat Kota dalam lingkungan Polresta Bandar Lampung, dalam rangka menciptakan keamanan, keselamatan ketertiban dan kelancaran Lalu Lintas (Kamseltibcar Lantas) Diwilayah Kota Bandar Lampung.

Tugas Pokok diatas merupakan penjabaran Program Kegiatan Satuan Lalu Lintas Polresta Bandar Lampung Tahun 2012 dilaksanakan sesuai kebijakan serta petunjuk teknis pembinaan fungsi yang dilaksanakan Oleh Satuan Lalu Lintas Polresta Bandar Lampung yaitu :

1) Memberikan bimbingan tehknis atas pelaksanaan fungsi Lalu Lintas pada unit-unit yang ada pada Satlantas Polresta Bandar Lampung.

2) Ikut serta dalam upaya pembinaan dan pengembangan fungsi tehknis Lalu Lintas, baik yang menyangkut metode maupun personil serta peralatan khusus yang digunakan untuk mendukung operasional pelaksanaan tugas di lapangan.

3) Menyelenggarakan dan melaksanakan pengkajian masalahmasalah Lalu Lintas pada tingkat Polresta termasuk masalah rekayasa tehnik Lalu Lintas di wilayah hukum Polresta Bandar Lampung demi terwujudnya situasi kamseltibcar Lantas yang aman tertib dan lancar.

4) Menyelenggarakan Administrasi Operasional termasuk pengumpulan, pengelolaan dan penyajian data/informasi baik berkenaan dengan aspek pembinaan maupun pelaksanaan fungsi lalu lintas.

5) Membuat perencanaan kegiatan yang akan dilaksanakan dan anggaran yang dibutuhkan untuk diajukan ke bagian perencanaan Polresta Bandar Lampung guna mendukung pelaksanaan operasional personil Satuan Lalu Lintas Polresta Bandar Lampung.

6) Membuat laporan hasil pelaksanaan tugas dan laporan pertanggungjawaban keuangan atas anggaran yang telah digunakan.

Pelaksanaan dari tugas pokok Satuan Lalu Lintas Polresta Bandar Lampung tersebut adalah : 
1) Membuat Rencana Kegiatan bidang Lalu Lintas Bulanan, Mingguan, dan Harian dengan mempedomani Program KerjaPolresta Bandar Lampung.

2) Membuat Kalender Kamseltibcar Lantas, Triwulan dan Semester.

3) Membuat Panel Data Dinamika Operasi (PDDO) yang merupakan ploting daerah rawan kecelakaan Lalu Lintas dalam jajaran Polresta Bandar Lampung.

4) Melakukan Analisa dan Evaluasi (Anev) permasalahan dibidang Lalu Lintas untuk pelaksanaan Gelar Operasi Bulanan.

5) Melaksanakan operasi Kepolisian baik operasi rutin maupun Operasi Kepolisian secara terpusat.

Menurut keterangan Kaurmin Ops Satuan Lalu Lintas Polresta Bandar Lampung bahwa hasil yang dicapai dalam pelaksanaan tugas tersebut adalah:

\section{Urmin Ops}

Menyelenggarakan administrasi personil, antara lain :

a) Menyusun rencana kegiatan tahun 2018

b) Membuat analisa beban kerja personil Satlantas tahun 2018 c) Menyusun rencana anggaran yang dibutuhkan tahun 2018

d) Menyediakan dan mendata sarana dan prasarana yang mendukung kegiatan operasional di lapangan.

e) Mendistribusikan kebutuhan personil di lapangan.

f) Membuat laporan pertanggungjawaban keuangan atas anggaran yang telah digunakan.

g) Menyiapkan daftar hadir personil setiap hari.

h) Penyampaian informasi terkait dengan kegiatan satuan lalu lintas Polresta Bandar Lampung kepada masyarakat melalui website, facebook, dan twitter dengan target dan pencapaian hasil sebagai berikut:

Tabel 1. Hasil Analisa Penggunaan Sarana Informasi pada Satuan Lalu Lintas Polresta Bandar Lampung

\begin{tabular}{|l|c|c|c|}
\hline \multirow{2}{*}{$\begin{array}{c}\text { Sarana } \\
\text { Informasi }\end{array}$} & \multicolumn{3}{|c|}{ Analisa Pencapaian } \\
\cline { 2 - 4 } & Target & Pencapaian & $\%$ \\
\hline Website & 1 & 1 & 100 \\
\hline Facebook & 360 & 365 & $100+$ \\
\hline Twitter & 360 & 365 & $100+$ \\
\hline Sumber : Dokumentasi & Polresta & Bandar \\
\hline
\end{tabular}
Lampung 2017

\section{Urbin Ops}

Menurut keterangan Kaurbin Ops Lantas Polresta Bandar Lampung bahwa upaya yang dilakukan agar tidak 
terjadi penyimpangan oleh Personil adalah :

a) Pemberian Penghargaan terhadap kinerja Anggota Satlantas Polresta Bandar Lampung yang berprestasi selama tahun 2012 dengan indikator personil dengan tilang terbanyak dan penyidik dengan SP2HP terbanyak serta personil yang memiliki dedikasi terbaik, sebagaimana tertera dalam tabelberikut:

Tabel 2. Analisa Pemberian Penghargaan Pada Satuan Lalu Lintas Polresta Bandar Lampung

\begin{tabular}{|c|c|c|c|}
\hline \multirow{2}{*}{$\begin{array}{c}\text { Pemberian } \\
\text { Penghargaan }\end{array}$} & $\begin{array}{c}\text { Targ } \\
\text { et }\end{array}$ & Pencapaian & $\%$ \\
\hline $\begin{array}{c}\text { Jumlah } \\
\text { kegiatan }\end{array}$ & 4 & 3 & 75 \\
\hline $\begin{array}{c}\text { Jumlah } \\
\text { Personil }\end{array}$ & 8 & 8 & 100 \\
\hline Sumber : Dokumentasi Polresta & Bandar
\end{tabular}
Lampung 2017

b) Pemberian sangsi Hukuman Kepada Anggota Satlantas Polresta Bandar Lampung yang tidak berprestasi dengan indikator personil yang jarang apel, personil yang jarang menilang dan personil unit Laka dengan SP2H paling sedikit, selama tahun 2012 yaitu :
Tabel 2. Analisa Pemberian Sangsi Pada Satuan Lalu Lintas Polresta Bandar Lampung

\begin{tabular}{|c|c|c|c|}
\hline Pemberian & \multicolumn{3}{|c|}{ Analisa Pencapaian } \\
\cline { 2 - 4 } Sangsi & Target & Pencapaian & $\%$ \\
\hline $\begin{array}{c}\text { Jumlah } \\
\text { kegiatan }\end{array}$ & 4 & 3 & 75 \\
\hline $\begin{array}{c}\text { Jumlah } \\
\text { Personil }\end{array}$ & 8 & 4 & 50 \\
\hline
\end{tabular}
Lampung 2017

\section{Unit Regident}

Berdasarkan keterangan Kepala Unit Registrasi dan Identifikasi (Regident) bahwa kegiatan yang dilaksanakan sesuai dengan tugas pokokdan fungsi adalah :

a) Peningkatan Pelayanan Publik dengan melaksanakan Standar Operasional (SOP) Prosedur Pelayanan SIM adalah SIM Corner dan SIM Keliling

b) Pembangunan dan peningkatan Sarana prasarana Pelayanan Publik, yaitu :

- memperbaiki Ruang Tunggu Pelayanan SIM Satpas Polresta Bandar Lampung.

- Memperbaiki Ruang Uji Teori SIM.

- Melengkapi Sarana Uji Praktek SIM.

- Memperbaiki Ruang Produksi SIM 
- Menyiapkan smooking area dan mengarahkan pemohon SIM atau masyarakat yang ingin merokok untuk merokok di areal Smoking Area yang telah ada.

- Menyiapkan loket informasi untuk melayani masyarakat yang memerlukan informasi

\section{Unit Dikyasa}

Menurut keterangan Kepala Unit Pendidikan dan Rekayasa Lalu Lintas (Dikyasa Lantas) Polresta Bandar Lampung bahwa kegiatan yang dilaksanakan sesuai dengan tugas dan fungsi Pendidikan dan Rekayasa Lalu Lintas (Dikyasa Lantas) Polresta Bandar Lampung adalah sebagai berikut :

a) Peningkatan kegiatan Road Safety patnership action dan Sosialisasi Undang UndangNomor 22 tahun 2009 tentang Lalu Lintas dan Angkutan Jalan Raya

b) Safety Riding (Cara berkendaraan dengan selamat)

c) Kampanye keselamatan lalu lintas

d) Kemitraan Global Keselamatan Lalu Lintas (Global Road Safety Partnership Action).

e) Koordinasi dengan Instansi terkait tingkat kota Bandar Lampung

f) Mapping daerah rawan macet g) Mapping daerah rawan kecelakaan Lalu Lintas (jumlah black spot)

h) Optimalisasi Pendataan ramburambu

i) Unit Turjawali Polresta Bandar Lampungdengan meningkatkan budaya melayani kepada para pemakai jalan dalam rangka menciptakan kamseltibcar lalu lintas melalui kegiatan :Polisi lalu lintas ada dimana-mana melalui kegiatan Polisi Tenda dan strong point pada daerah rawan macet, rawan kecelakaan dan rawan pelanggaran Lalu lintas dengan Pola Pagi-siang dan sore-malam Satlantas Polresta Bandar Lampung

j) Patroli Ran-mor roda dua maupun roda empat pada daerah- daerah rawan laka, langgar serta macet dan rawan akan street crime/ kejahatan jalanan sesuai dengan beat-beat yang telah ditentukan

k) Melaksanakan kegiatan pengawalan dibidang lalu lintas kepada VVIP/VIP dan kegiatan masyarakat baik yang minta maupun tidak.

1) Unit Kecelakaan Lalu Lintas (Laka Lantas)Polresta Bandar Lampungdengan tugas pokok dan fungsi Unit Laka adalah sebagai berikut : 
- Penindakan pelanggaran Lalu

Lintas

- Peningkatan

Pelayanan

penanganan kecelakan Lalu

Lintas

- Profesionalisme penanganan

TPTKP

- Optimalisasi pemberian SP2HP

- Penyelesaian Kasus Kecelakaan

Lalu Lintas Polresta Bandar

Data hasil wawancaradengan informan Kaurbin Ops, Kaurmin, Kanit Turjawali, Kanit Regident, Kanit Dikyasa dan Kanit Laka diketahui bahwa kinerja Satuan Lalu Lintas Kepolisian Resort Kota (Polresta) Bandar Lampung sudah berjalan secara maksimal dan baik, sesuai dengan tugas pokok dan fungsi masing-masing. Berbagai bukti bahwa Satuan Lalu Lintas Kepolisian Resort Kota (Polresta) Bandar Lampung sudah melakukan tugas dengan baik.

\section{Kinerja Satuan Polisi Lalu} Lintas Polresta Bandar Lampung secara maksimal tersebut terbukti mampu menurunkan angka pelanggaran lalu lintas dan kecelakaan lalu lintas di Kota Bandar Lampung walaupun penurunannya belum maksimal.Hal ini dapat dilihat dari data yang penulis peroleh melalui dokumetasi Satuan Lalu Lintas Polresta Bandar Lampung tentang perbandingan angka pelanggaran lalu lintas tahun 2016 dengan tahun 2017.

Penanggulangan kasus kecelakaan lalu lintas dan pelanggaran lalu lintas pada periode Tahun 2017 secara umum mengalami penurunan dibandingkan dengan periode Tahun 2016 yaitu :

- Total kecelakaan lalu lintas dari 362 kasus turun menjadi 323 kasus,

- Total Pelanggaran Lalu Lintas dari 53.629 kasus menjadi 31.965 kasus,

Tingkat keberhasilan tersebut merupakan hasil kegiatan yang telah dilakukan oleh Satuan Lalu Lintas Polresta Bandar Lampung beserta jajarannya dengan upaya :

1) Pemantauan situasi Kamseltibcar lalu lintas melalui Panel Data Dinamika Operasi Rutin (PDDO) yang dievalusai pada setiap bulannya tentang perkembangan daerah rawan baik pelanggaran maupun rawan kecelakaan Lalu Lintas yang terjadi di wilayah Polresta Bandar Lampung

2) Meningkatkan kegiatan turjawali dengan prioritas pada lokasi rawan kecelakaan, rawan macet, rawan 
pelanggaran dengan bentuk kegiatan

Rekayasa dan Dikmas Lantas serta penindakan pelanggaran Lalu Lintas yang ditingkatkan.

3) Memberikan sosialisasi tentang Undang-undang Nomor 22 tahun 2009 tentang lalu lintas dan angkutan jalan kepada masyarakat baik secara langsung kepada masyarakat dan pelajar dengan cara mengunjungi sekolah-sekolah, kampus-kampus dengan giat police go to school dan police go to campus, melalui media elektronik dengan bekerja sama dengan RRI Pro 2 FM mengajak warga masyarakat kota Bandar Lampung untuk selalu tertib dan patuh terhadap aturan lalu lintas yang ada guna mewujudkan situasi kamseltibcar lantas yang tertib dan lancar.

4) Mensosialisasikan dan mengajak warga masyarakat pemakai jalan untuk menjadi pelopor keselamatan berlalu lintas dan menjadikan keselamatan berlalu lintas sebagai suatu kebutuhan.

Pelaksanakan Kawasan Tertib Lalu Lintas.

1) Pemberlakuan kawasan tertib Lalu Lintas pada wilayah hukum Polresta Bandar Lampung secara serentak telah dilaksanakan sejak tanggal 1 Maret 1995.

2) Keputusan Walikota Bandar Lampung Nomor : 41/12/HK/2011 tanggal 20 Januari 2011 tentang Penetapan Kawasan Tertib Berlalulintas dalam Kota Bandar Lampung, yaitu penggal Jalan Jendral Sudirman, Jalan Jenderal Ahmad Yani, Jalan RA. Kartini dan Jalan Raden Intan.

3) Kegiatan yang dilaksanakan oleh Satuan Lalu LintasPolresta Bandar Lampung beserta jajarannya dalam upaya memberikan Informasi kepada masyarakat tentang pelaksanaan Kawasan Tertib Lalu Lintas melalui kegiatan penyuluhan, penerangan langsung kepada sekolah-sekolah, kantor Instansi yang berlokasi disekitar yang berlokasi disekitar Kawasan tertib Lalu Lintas untuk mematuhi dan mendukung pelaksanaan Kawasan Tertib Lalu Lintas.

Faktor faktor yang masih mempengaruhi kinerja Satuan Lalu Lintas Polresta Bandar Lampung antara lain; masih kurangnya jumlah personil Lalu Lintas bila dibanding dengan luasnya wilayah dan padatnya penduduk Kota Bandar Lampung; masih 
kurangnya sarana pendukung seperti kendaraan patroli baik roda dua maupun roda empat, banyaknya kendaraan di Kota Bandar Lampung dan belum diimbanginya dengan perbaikan dan penambahan inprastruktur jalan, masih banyak rambu-rambu lalu lintas yang tidak berfungsi, kurangnya kesadaran masyarakat akan pentingnya ketertiban berlalu lintas (tidak melengkapi diri dengan surat-menyurat kendaraan, tidak memakai helm, sabuk pengaman,dll.).

Berdasarkan hasil pembahasan di atas dapat disimpulkan bahwa kinerja maksimal yang dilakukan oleh Satuan Lalu Lintas Kepolisian Resort Kota (Polresta) Bandar Lampung telah berhasil menurunkan angka pelanggaran dan angka kecelakaan lalu lintas di Kota Bandar Lampung atau dengan kata lain Satuan Lalu Lintas Kepolisian Resort Kota (Polresta) Bandar Lampung telah berhasil meningkatkan ketertiban lalu lintas di Kota Bandar Lampung.

\section{SIMPULAN DAN SARAN}

\section{Simpulan}

Berdasarkan hasil penelitian dan pembahasan, maka penulis dapat mengambil beberapa kesimpulan yaitu :
1. Satuan Lalu Lintas Polresta Bandar Lampung, sudah melaksanakan tugas pokok dan fungsinya yaitu bertugas untuk menyelenggarakan dan membina fungsi lalulintas kepolisian, meliputi penjagaan, pengaturan, pengawalan dan patroli, pendidikan masyarakat dan rekayasa lalulintas, registrasi dan identifikasi, penyidikan kecelakaan lalu lintas dan penegakan hukum bidang lalulintas, guna memelihara keamanan, keselamatan, ketertiban dan kelancaran lalulintas

2. Pelaksanaan tugas pokok dan fungsi Satuan Lalu Lintas Polresta Bandar Lampung tersebut membuktikan bahwa kinerja Satuan Lalu Lintas Polresta Bandar Lampung sudah terlaksana dengan baik.

3. Kinerja yang baik dari Satuan Lalu Lintas Polresta Bandar Lampung dapat meningkatkan ketertiban lalu lintas di Kota Bandar Lampung. indikator meningkatnya ketertiban lalu lintas adalah menurunnya angka pelanggaran dan kecelakaan lalu lintas pada tahun 2017 dibandingkan dengan tahun 2016.

4. Masih terjadinya banyak pelanggaran dan kecelakaan lalu lintas di Kota Bandar Lampung walaupun kinerja Satuan Lalu Lintas Polresta Bandar 
Lampung sudah dilaksanakan secara maksimal disebabkan oleh faktor manusia yang tidak mentaati aturan lalu lintas, faktor banyaknya kendaraan yang tidak diimbangi oleh penambahan infrastruktur jalan, serta masih banyak rambu-rambu lalu lintas yang tidak berfungsi.

\section{Saran}

Saran yang penulis sampaikan melalui karya ilmiah ini adalah sebagai berikut :

1. Hendaknya Kepala Kepolisian Daerah Lampung maupun Kepala Kepolisian Resort Kota Bandar Lampung dapat menambah sarana pendukung untuk kegiatan operasional di lapangan, sehingga tugas-tugas Satuan Lalu Lintas Polresta Bandar Lampung dapat dilaksanakan secara cepat, tepat, efektif dan efisien.

2. Guna meningkatkan kwalitas personil Satuan Lalu Lintas Polresta Bandar Lampung, hendaknyaKepala Kepolisian Daerah Lampung maupun Kepala Kepolisian Resort Kota Bandar Lampungmemberikan kesempatan bagi personil untuk mengikuti pendidikan maupun pelatihan khusus di bidang Lalu Lintas.

3. Hendaknya personil Satuan Lalu Lintas Polresta Bandar Lampung dapat melaksanakan tugas penjagaan dan pengaturan lalu lintas selama 24 jam secara bergantian, agar ketertiban lalu lintas di Kota Bandar Lampung benar-benar dapat terwujud.

4. Kepada masyarakat pengguna jalan raya, hendaknya mentaati semua peraturan lalu lintas, agar ketertiban, keamanan, kenyamanan dan keselamatan diri kita maupun orang lain di jalan raya dapat terwujud.

\section{DAFTAR PUSTAKA}

Aprilia, 2014. Pengertian Pelayanan

Prima dan dasar-dasar Pelayanan Prima. Universitas Airlangga, Surabaya

Herdiansyah, Haris,2012,Metodologi Penelitian Kualitatif untuk IlmuIlmu Sosial, Salemba Humanika, ,Jakarta:

Ismail, Chaerudin. (1998). Polisi, Kredibilitas, dan Reputasi Polisi Pengayom vs Penindas. Citra Indonesia. Jakarta

\section{Koentjaraningrat,1994 Metode-metode Penelitian Masyarakat.Gramedia: Jakarta.}

Lukito, Penny, Kusumastuti, 2014, Membumikan Transparansi Dan 
Akuntabilitas Kinerja Sektor Publik: Tantangan Demokrasi KeDepan. PT Gramedia Widiasarana Indonesia, Jakarta.

Moeheriono. 2012. Pengukuran Kinerja Berbasis Kompetensi. Raja Grafindo Persada, Jakarta:

Mulyadi, Mohammad,2011,Penelitian Kuantitatif dan Kualitatif, Nadi Pustaka, Yogyakarta,

Sedarmayanti. 2009. "Sumber Daya Manusia dan Produktivitas Kerja”. Bandung: Mandar Maju

Singarimbun, 1998, Metode Penelitian dan Survey, Rajawali, Jakarta.

UU RI No 17 Tahun 2007 tentang Rencana Pembangunan Jangka Panjang Nasional (RPJPN) tahun 2005-2025

UU RI No. 2 Tahun 2002 Tentang Kepolisian.

UU RI No. 22 Tahun 2009 Tentang Lalu Lintas dan Angkutan Jalan

Keputusan Walikota Bandar Lampung Nomor : 41/12/HK/2011 tanggal 20 Januari 2011 tentang Penetapan Kawasan Tertib Berlalulintas dalam Kota Bandar Lampung 